\title{
KONSTRUKSI MAKNA PEREMPUAN PERGERAKAN
}

\author{
Pitri Indriyani $^{1 *}$, Eka Yusuf ${ }^{2}$, dan Muhammad Ramdhani ${ }^{3}$ \\ ${ }^{1,2,3}$ Universitas Singaperbangsa Karawang, Jawa Barat. \\ *pitriindriyani06@gmail.com
}

\begin{abstract}
The phenomenon of women's movements is still not common in the ears of Indonesian society, but in fact the previous women's struggles have brought freedom over their rights to women today. So that the existence of women is no longer considered low. Because women are present in every line, both in education, politics and socially. This study, with the "Study of the Construction of the Meaning of Women Movement for KOPRI in Karawang Regency" uses a qualitative method and a phenomenological approach, because in this study the researcher wants to find out a problem and also a phenomenon that comes from the experience of the informants directly experienced, and also looking to find out about the motives, meanings and experiences of female movements. The theories used in this research are Symbolic Interaction Theory, Phenomenology Theory, and Social Reality Construction Theory which is the basis for researchers in conducting this research. The results obtained after obtaining data from informants regarding the meaning of women's movements according to their point of view are when women can provide benefits and also when women are the spearhead of civilization. The meaning they express is based on their experiences who have carried out humanitarian actions such as raising funds and volunteering for disasters and also opening a reading room as a means of reading for the people of Karawang in the hope of arousing the spirit of reading the Karawang people.
\end{abstract}

Keywords: phenomenon; female movement; meaning.

\begin{abstract}
Abstrak
Fenomena perempuan pergerakan memang masih belum lazim di telinga masyarakat Indonesia, namun kenyataannya perjuangan perempuan terdahulu telah mengantarkan kebebasan atas haknya kepada perempuan hari ini. Sehingga keberadaan perempuan tidak lagi dianggap rendah. Karena perempuan hadir di setiap lini, baik dalam pendidikan, politik, maupun sosial. Penelitian ini dengan "Studi Fenomenologi Konstruksi Makna Perempuan Pergerakan Bagi KOPRI di Kabupaten Karawang" ini menggunakan metode kualitatif dan pendekatan fenomenologi, karena dalam penelitian ini peneliti ingin mencari tahu suatu masalah dan juga fenomena yang berasal dari pengalaman para informan yang dialami secara langsung, dan juga mencari tahu tentang suatu motif, makna dan pengalaman perempuan pergerakan.Teori yang digunakan pada penelitian kali ini adalah Teori Interaksi Simbolik, Teori Fenomenologi, dan juga Teori Konstruksi Realitas Sosial yang menjadi landasan peneliti dalam melakukan penelitian ini. Hasil yang didapat setelah mendapatkan data dari para informan mengenai makna diri perempuan pergerakan menurut sudut pandang mereka ialah ketika perempuan bisa memberi manfaat dan juga ketika perempuan menjadi ujung tombak peradaban. Makna yang mereka ungkapkan berdasarkan pengalaman mereka yang telah melakukan aksi kemanusiaan seperti menggalang dana dan menjadi relawan bencana dan juga telah membuka ruang baca sebagai sarana membaca bagi masyarakat Karawang dengan harapan bisa membangkitkan semangat membaca masyarakat Karawang.
\end{abstract}

Kata Kunci: fenomena; perempuan pergerakan; makna.

\section{PENDAHULUAN}

Korps Pergerakan Mahasiswa Islam Indonesia Puteri yang disingkat menjadi KOPRI merupakan Badan Semi Otonom
Pergerakan Mahasiswa Islam Indonesia (PMII), organisasi mahasiswa eksternal kampus, yang fokusnya pada sisi agamis, nasionalis dan humanis. Kopri sendiri ada sebagai wadah 
PMII puteri untuk menampung aspirasi perempuan, sebagai tempat dan menjalankan kerja-kerja organisasi di bidang keperempuanan.

Dalam PMII, ada istilah yang namanya warga pergerakan. Pergerakan di sini maksudnya kegiatan dan arah gerakan yang dilakukan oleh organisasi PMII, dan sebaikbaiknya pergerakan adalah pergerakan yang memberikan manfaat bagi kehidupan bersosial. Sebagaimana kita ketahui bahwa peran mahasiswa salah satunya ialah sebagai agent of social control, mahasiswa dituntut untuk peka terhadap isu maupun keadaan yang sedang terjadi baik itu pada tatanan kampus, pemerintah, maupun masyarakat. Kopri nya sendiri istilah itu dinamakan sebagai Perempuan Pergerakan, layaknya mahasiswa merangkap jadi organisatoris atau sebut saja sebagai aktivis, juga harus memberikan manfaat untuk kemaslahatan banyak orang minimalnya untuk diri sendiri dan sesama perempuan, seperti yang dikatakan oleh salah satu Kopri Universitas Singaperbangsa Karawang (UNSIKA) pada wawancara prapenelitian, Hosi mengatakan "sebagai perempuan sudah seharusnya kita show up dan membuktikan pada dunia, bahwa kita samasama punya mimpi, kita berhak untuk wujudkan mimpi itu. Jangan karena kita terlahir sebagai perempuan, kita dibatasi dengan dinding-dinding pembodohan dan penindasan".

Beda halnya dengan laki-laki, bagi perempuan, jangankan menjadi perempuan pergerakan, untuk mendapatkan pendidikan yang layak saja tidak diperbolehkan, karena beranggapan bahwa setinggi-tingginya jenjang pendidikan yang dikenyam perempuan kelak ketika sudah menikah, seorang istri hanya boleh mengerjakan pekerjaan rumah saja, dan tidak boleh bekerja diluar rumah. Misalnya saja, untuk pekerjaan domestik sudah sejak lama dilekatkan pada perempuan (Tuwu, 2018), apalagi sampai mempunyai penghasilan yang melebihi penghasilan suami, sehingga pendidikan yang diperoleh tidak akan berguna ketika sudah memasuki kehidupan berumah tangga. Walaupun mungkin perempuan dibesarkan dalam lingkungan keluarga yang moderat tetapi masyarakat luas secara umum masih menganggap kondisi ini sebagai kondisi yang aneh atas tidak semestinya. Penelitian yang dilakukan oleh Kate Ratliff, $\mathrm{PhD}$, dari Universitas California menyatakan bahwa lakilaki terusik egonya, merasa minder, bersalah dan gagal dalam menjalankan perannya sebagai suami ketika istri memiliki penghasilan lebih besar atau memiliki karir yang lebih cemerlang dibandingkan dirinya. Kondisi tersebut sangat berpeluang menimbulkan konflik, baik dalam diri maupun keluarga (Kompasiana, 2015).

Jika mengingat kembali kilas perempuan pergerakan yang sudah memberikan perubahan untuk kemaslahatan banyak orang, dan saat ini bisa dirasakan kebermanfaatannya, kita tahu ada Raden Ajeng Kartini, yang bergerak melawan diskriminasi terhadap perempuan dalam hal pendidikan. Beliau salah satu pelopor pendidikan perempuan di Indonesia. R.A. Kartini berasal dari kalangan bangsawan, untuk mendapatkan pendidikan tentunya bukanlah hal yang sulit jika dilihat dari sisi materi. Namun karena R.A. Kartini terlahir sebagai perempuan, tetap saja nasibnya sama seperti perempuan-perempuan lainnya, pendidikan bukanlah haknya, R.A. Kartini dilarang untuk melanjutkan pendidikannya ke jenjang yang lebih tinggi. Dengan pandangannya yang cukup luas, sehingga R.A Kartini sebagai pihak muda yang sudah dididik dengan pengajaran barat turut mempengaruhi arah pemikirannya dalam yang berusaha untuk memperjuangkan emansipasi wanita (Hartutik, 2015).

Maka sudah seharusnya, pergerakan perempuan-perempuan hari ini harus lebih maju. Perempuan adalah salah satu makhluk ciptaan Tuhan yang paling sempurna. Memiliki akal serta harkat dan martabat yang membedakan dari makhluk yang lain. Nilainilai, harkat, derajat, dan martabat yang dimiliki oleh manusia haruslah dijunjung tinggi dan dilindungi. Dengan demikian, hak-hak yang dimiliki oleh setiap manusia pun dapat terlindungi juga. Kesempatan sudah dibuka 
lebar-lebar untuk mengekspresikan apa yang menjadi keinginan dan cita-cita perempuan.

Mengacu pada fenomenologi sebagai pedoman dalam melakukan penelitian, penulis berusaha menjadikan makna dari sebuah realitas berdasarkan pengalaman yang dilalui oleh manusia. Realitas yang dimaksud penulis adalah pengalaman hidup dan makna perempuan pergerakan bagi Kopri. Penulis tertarik untuk melakukan penelitian yang diuraikan pada latar belakang diatas dengan tujuan yang hendak dicapai oleh peneliti dalam mengerjakan penelitian ini adalah untuk mengetahui makna perempuan pergerakan bagi KOPRI.

Penelitian yang relevan adalah "Konstruksi Makna Perempuan Perokok (Studi Fenomenologi Konstruksi makna Perempuan Perokok di Karawang)", Program Studi Ilmu Komunikasi, Fakultas Ilmu Sosial dan Ilmu Politik, Universitas Singaperbangsa Karawang, Karawang, (2019). Dalam penelitian ini disebutkan bahwa perempuan perokok merupakan fenomena yang menjadi sebuah realitas. Para perempuan perokok tersebut memiliki makna tentang perempuan perokok dengan pemahaman dan pandangannya masing-masing. Pada penelitian ini, peneliti menggunakan metode penelitian kualitatif dengan pendekatan fenomenologi.

Hasil dari penelitian ini menunjukkan bahwa informan mengetahui informasi tentang adanya zat zat berbahaya yang terkandung di dalam rokok dan pengaruh rokok terhadap kesehatan. Setiap informan memberikan penjelasan yang berbeda terkait makna perempuan perokok. Lingkungan menjadi faktor utama yang mempengaruhi informan untuk merokok. Selain itu, keluarga juga turut pula menjadi faktor yang mempengaruhinya. Salah satu motif dari keinginan informan untuk merokok yaitu karena rasa penasaran untuk mencoba hal yang baru, juga kebiasaan berada dilingkungan yang notabenenya perokok semua. Dari sanalah hasrat informan untuk merokoknya muncul hingga menjadi perokok aktif bahkan bisa dibilang menjadi pecandu rokok. Kesimpulan dari penelitian ini adalah makna dari perempuan perokok saat ini disadari oleh pemahaman yang ditentukan mereka secara subjektif. Jadi, makna perempuan perokok diartikan berbeda oleh setiap individu (informan penelitian). Secara garis besar, makna perempuan perokok telah mengalami pergeseran. Hal ini dipengaruhi oleh pengalaman yang berbeda dari masing-masing individu.

Penelitian yang kedua dengan judul "Kepemimpinan Perempuan Dalam Meningkatkan Kinerja Organisasi Pada KOPRI (Korps PMII Putri) wilayah Lampung (Siti Wuryan, 2019). Penelitian ini dilakukan untuk mengetahui kepemimpinan seorang perempuan untuk meningkatkan kinerja dalam sebuah organisasi. Dalam penelitian ini penulis mengkhususkan pada kepengurusan KOPRI Wilayah Lampung yang beralamatkan di Jalan Pahlawan Gang Cempaka, Nomor 40 Kecamatan Kedaton Kota Bandar Lampung. Kepemimpinan perempuan dalam peningkatan kinerja organisasi pada KOPRI Wilayah Lampung, maka penulis dapat menyimpulkan tipe kepemimpinan yang digunakan oleh KOPRI Wilayah Lampung ialah tipe kepemimpinan demokratik, hal ini dapat diketahui bahwa setiap akan merencanakan maupun menetapkan keputusan atau kebijakan selalu mengedepankan musyawarah, serta tidak menutup kemungkinan argumentasi dari anggota menjadi keputusan yang disepakati oleh organisasi. Pelaksanaan kegiatan di KOPRI secara umum memberikan manfaat yang berarti bagi anggota walaupun tidak berjalan dengan baik.

Dari penelitian diatas dapat disimpulkan bahwa setiap penelitian yang dilakukan oleh masing-masing peneliti terdapat persamaan dan perbedaan, keaslian penelitian ini dapat dipertanggungjawabkan, peneliti meyakini bahwa penelitian yang peneliti susun dengan judul "Konstruksi Makna Perempuan Pergerakan" belum pernah diteliti dengan subjek perempuan yang mengikuti Korps Pergerakan Mahasiswa Islam Indonesia Puteri (KOPRI) itu sendiri yang berada di daerah Kabupaten Karawang. Peneliti tertarik untuk 
melakukan penelitian ini karena hal yang unik mengenai istilah Perempuan Pergerakan yang ditujukan kepada para perempuan yang menjadi KOPRI dan makna bagi KOPRI itu sendiri.

Penelitian ini menggunakan pendekatan fenomenologi yang dikenal sebagai aliran filsafat sekaligus metode berfikir, yang mempelajari fenomena manusiawi (human phenomena) tanpa mempertanyakan penyebab dari fenomena itu, realitas objektifnya dan penampakannya. Fenomenologi tidak beranjak dari kebenaran fenomena seperti yang tampak apa adanya, namun sangat meyakini bahwa fenomena yang tampak itu adalah objek yang penuh dengan makna transendental. Oleh karena itu, untuk mendapatkan hakikat kebenaran, maka harus menerobos melampaui fenomena yang tampak itu.

Tujuan utama fenomenologi adalah mempelajari bagaimana fenomena dialami dalam kesadaran, pikiran dan dalam tindakan, seperti bagaimana fenomena tersebut bernilai dan diterima secara estetis (Kuswarno, 2013:35-37). Teori-teori dalam tradisi fenomenologi berasumsi bahwa orang-orang secara aktif menginterpretasikan pengalamanpengalamannya dan mencoba memahami dunia dengan pengalaman pribadinya. Proses mengetahui dengan pengalaman langsung merupakan wilayah kajian fenomenologi. Dalam kajian komunikasi yang digunakan manusia untuk memahami dunia melalui pengalaman langsung. Peneliti hendak mengetahui makna seorang perempuan pergerakan dengan sadar menganalisi serta menguji persepsi dan perasaan tentangnya. Juga teori konstruksi realitas sosial pada penelitian ini dapat menggambarkan proses sosial seorang KOPRI melalui tindakan dan interaksi dimana KOPRI atau sekelompok individu menciptakan secara terus menerus suatu realitas yang dimiliki dan dialami bersama secara subjektif.

Oleh karena itu, sebuah realitas yang diamati oleh peneliti tidak bisa digeneralisasikan kepada semua orang. Dalam paradigma, hubungan antara pengamat dan objek merupakan satu kesatuan, subjektif dan merupakan hasil perpaduan interaksi antar keduanya (Moleong, 2010:70). Selain teori fenomenologi dan teori konstruksi realitas sosial dari Berger dan Luckman, fenomena perempuan pergerakan juga dapat dilihat dari pandangan teori interaksi simbolik. Konsep teori interaksi simbolik ini diperkenalkan oleh Herbert Blumer sekitar tahun 1939. Definisi yang mereka berikan kepada orang lain, situasi, objek dan bahkan diri mereka sendiri yang menentukan perilaku manusia.

Secara etimologis perempuan berasal dari kata empu yang yang berarti tuan, yaitu orang yang mahir atau berkuasa, kepala, hulu, yang paling besar. Namun menurut Zaitunah Subhan dalam GL Yordani (tanpa tahun) kata perempuan berasal dari kata empu yang artinya dihargai. Sedangkan gambaran tentang perempuan menurut pandangan yang didasarkan pada kajian medis, psikologis dan sosial, terbagi atas dua faktor, yaitu faktor fisik dan psikis. Secara biologis dari segi fisik, perempuan dibedakan atas dasar fisik perempuan yang lebih kecil dari laki-laki, suaranya lebih halus, perkembangan tubuh perempuan terjadi lebih dini, kekuatan perempuan tidak sekuat laki-laki dan sebagainya. Dari segi psikis, perempuan mempunyai sikap pembawaan yang kalem, perasaan perempuan lebih cepat menangis dan bahkan pingsan apabila menghadapi persoalan berat (Muthahhari dalam GL Yordani, tanpa tahun). Menurut Kartini Kartono (dalam GL Yordani, tanpa tahun), perbedaan fisiologis yang dialami sejak lahir pada umumnya kemudian diperkuat oleh struktur kebudayaan yang ada, khususnya oleh adat istiadat. Perbedaan biologis yang sering dikaitkan dengan gender menjadikannya digunakan untuk menentukan relati gender, seperti pembagian hak dan kewajiban, fungsi, peran dan status dalam masyarakat. Lebih jauh lagi, ketertarikan fungsi dan dan peran antara perempuan dan laki-laki sangat berpengaruh dalam keutuhan masyarakat (Ikhma Zurani, 2020).

Reformasi politik pada tahun 1998 telah membawa angin perubahan pada situasi politik 
di Indonesia, setidaknya dari sistem otoriter menuju demokrasi, dari sistem pemerintahan yang tersentralisasi menjadi terdesentralisasi, dan dari supremasi militer ke supremasi sipil. Perubahan ini membawa implikasi bagi gerakan sosial politik di Indonesia termasuk gerakan perempuan.

Gerakan perempuan Indonesia turut terlibat dan menjadi bagian penting dalam perjuangan budaya politik baru yang berlandaskan pada etika kepedulian di tengah budaya politik yang maskulin. Hal ini tampak pada tindakan dan strategi yang diambil gerakan perempuan dalam menghadapi kerusuhan Mei 1998 dan konflik sosial dengan menggunakan isu SARA (Suku, Agama, Ras dan Antargolongan) di berbagai daerah.

Berbicara mengenai keperempuanan, Indonesia butuh perempuan pergerakan yang senantiasa melakukan gerakan-gerakan perubahan untuk menumpas ketidakadilan yang melemahkan dan mendiskriminasi perempuan. Tentunya, semua itu dilakukan oleh perempuan pergerakan, yang mau bergerak dan memastikan keadilan yang sesungguhnya bisa perempuan miliki dengan utuh. Kita mengenal R. A Kartini, seorang perempuan pergerakan kelahiran Jepara 21 April 1879. Beliau dikenang sebagai pelopor pendidikan bagi perempuan.

Dengan pandangannya yang cukup luas, sehingga R.A Kartini sebagai pihak muda yang sudah dididik dengan pengajaran barat turut mempengaruhi arah pemikirannya dalam yang berusaha untuk memperjuangkan emansipasi wanita (Hartutik, 2015)

Perjuangan R.A Kartini mewarnai sejarah perempuan pergerakan yang patut diacungi jempol atas keberaniannya melawan ketertindasan, ketidakberpihakan pada perempuan, yang sudah mengakar dan menjadi budaya patriarki di bumi Indonesia. Dalam situasi tersebut, perempuan pergerakan harus terus mencari bentuk dan pemikiran untuk mendorong perempuan lebih berani muncul bahkan di ranah publik, mulai dari tingkat nasional hingga akar rumput. Aksi kolektif perempuan adalah salah satu metode gerakan perempuan yang bertujuan untuk mengajukan tuntutan di ranah publik dengan tetap membawa identitas gender perempuan, juga merambah persoalan publik yang lebih luas, kelestarian lingkungan dan keadilan sosial. Semua tindakan kolektif yang melibatkan aktor kolektif dan diskursus gender tersebut menegaskan gerakan perempuan punya dampak dan daya dorong bagi perubahan sosial yang penting bukan hanya bagi keluarga, tetapi juga organisasi, pemerintah dan masyarakat secara luas.

Menjadi seorang perempuan pergerakan tentunya bukanlah semata-mata muncul secara sendirinya, pasti ada motif yang melatarbelakangi. Motif sendiri merupakan dorongan dalam diri manusia yang timbul dikarenakan adanya kebutuhan-kebutuhan yang ingin dipenuhi oleh manusia tersebut. Menurut Rakhmat (dalam Bayu, 2019:30), motif efektif menekankan aspek perasaan dan kebutuhan mencapai tingkat emosional tertentu. Motif itu merupakan suatu pengertian yang melingkupi semua penggerak, alasan-alasan atau dorongandorongan dalam diri manusia yang menyebabkan ia berbuat sesuatu. Semua tingkah laku manusia pada hakikatnya mempunyai motif juga tingkah laku yang disebut tingkah laku secara reflex dan yang berlangsung secara otomatis, mempunyai maksud tertentu walaupun maksud itu tidak senantiasa sadar bagi manusia.

Selain memiliki motif untuk menjadi perempuan pergerakan, mereka juga mempunyai makna tersendiri mengenai perempuan pergerakan. Upaya memahami makna sesungguhnya merupakan salah satu masalah filsafat tertua dalam umur manusia, karena konsep makna telah menarik disiplin komunikasi, psikologi, sosiologi, antopologi dan lingistik. Itu sebabnya beberapa pakar komunikasi sering menyebutkan kata makna ketika mereka mendefinisikan komunikasi. Makna telah menarik perhatian para pemikir dan sarjana sosial bagi Spradley, makna merupakan penyampaian pengalaman sebagai umat besar manusia didalam masyarakat. Begitu banyaknya orang yang mendefinisikan 
makna sehingga hampir membuat makna kehilangan maknanya (Sobur, 2013).

Meninjau kembali fenomenologi secara sosial menurut Alfred Schutz bahwa konstruksi makna adalah sumbangan yang penting dan orisinil untuk pemikiran fenomenologi. Pemaknaan terjadi karena cara dan proses berpikir berbeda pada setiap individu yang akan menghasilkan keragaman dalam pembentukan makna (Brouwer, 1994). Makna tidak akan sama setiap individu walaupun objek yang dihadapinya sama. Untuk itu dalam upaya mengkaji esensi realitas pada perempuan yang menjadi KOPRI di Kabupaten Karawang, bagaimana gambaran konstruksi makna perempuan pergerakan itu sendiri akan dikaji secara komprehensif karena tema konstruksi makna adalah salah satu tujuan pada penelitian ini.

\section{METODOLOGI}

Metodologi penelitian didefinisikan sebagai proses, prinsip dan prosedur yang digunakan dalam mendekati masalah, mengkaji, dan mencari jawaban dari topik penelitian. Dengan kata lain metodologi adalah suatu pendekatan umum untuk mengkaji topik penelitian. Metodologi dipengaruhi atau berdasarkan perspektif teoritis itu adalah suatu kerangka penjelasan atau interpretasi yang memungkinkan peneliti memahami data dan menghubungkan data yang rumit dengan peristiwa dan situasi (Mulyana, 2011). Penelitian ini menggunakan pendekatan kualitatif dimana peneliti menggunakan data deskriptif berupa kata-kata tertulis atau lisan dari orang-orang dan perilaku yang dapat diamati. Metode kualitatif berlandaskan pada firasat postpositivisme, digunakan untuk meneliti pada kondisi objek yang alamiah (sebagai lawannya adalah eksperimen) dimana peneliti adalah sebagai instrument kunci, pengambilan sample, sumber dan data dilakukan secara purposif, teknik pengumpulan data dilakukan dengan trigulasi (gabungan) analisis data bersifat induktif/kualitatif, dan hasil penelitian kualitatif lebih menekankan pada makna dari generalisasi (Sugiyono, 2013).
Sejalan dengan definisi tersebut dalam Moleong (2017:4) Krik dan Miller mendefinisikan bahwa penelitian kualitatif adalah tradisi tertentu dalam ilmu pengetahuan sosial yang secara fundamental bergantung dari pengamatan pada manusia baik dalam kawasanya maupun dalam peristilahannya. Penelitian menggunakan latar alamiah, dengan maksud menafsirkan fenomena yang terjadi dan dilakukan dengan jalan melibatkan berbagai metode yang ada"

Penelitian kualitatif berasumsi bahwa setiap individu, budaya, latar belakang adalah unik dan penting untuk mengapresiasikan keunikan, generalisasi bergantung pada konteks, memahami fenomena sosial melalui gambar holistik dan memperbanyak pemahaman mendalam. Sedangkan penelitian kualitatif adalah penelitian realita sosial yang tidak berasal dari persepsi subjektif dan terpisah dari konteks, menjelaskan, meramalkan fenomena melalui pengumpulan data.

Pada penelitian kali ini, subjek yang akan peneliti ambil adalah seorang perempuan yang menjadi Korps PMII Puteri (KOPRI) dalam organisasi Pergerakan Mahasiswa Islam Indonesia (PMII), yang berada di daerah Kabupaten Karawang. Dimana peneliti melihat fenomena mahasiswa yang mengikuti organisasi Pergerakan Mahasiswa Islam Indonesia menjadi perhatian. Salah satunya karena gerakan sosialnya yang seringkali dianggap negatif dan bisa dikatakan sebagai tukang rusuh dan pembuat onar, namun dalam hal ini peneliti hanya terfokus terhadap aktivis perempuannya saja.

\section{HASIL DAN PEMBAHASAN}

Fenomena perempuan pergerakan memang bukanlah istilah yang familiar di telinga masyarakat di Indonesia ini dan menimbulkan pro dan kontra. Hal ini dikarenakan memang sebagian besar masyarakat Indonesia masih menganut segala peraturan yang mengikat hak dan kewajiban seseorang yang diatur berdasarkan seks biologisnya. Sehingga memang banyak perdebatan yang terjadi dikarenakan 
perempuan yang banyak beraktivitas diluar rumah ini dianggap menyimpang dan berbeda atau melanggar norma sosial yang ideal.

Di Karawang sendiri istilah perempuan pergerakan ini masih belum banyak diketahui, hanya segelintir orang saja yang memang mengetahui apa itu perempuan pergerakan. Orang yang menjadi perempuan pergerakan pasti memiliki motif tersendiri, adapun motif perempuan pergerakan adalah sebagai berikut :

Pertama, motif menjalankan amanah guru, motif dapat menjadikan seseorang lebih bersemangat untuk melakukan sesuatu. Motif itu dapat terbentuk salah satunya dikarenakan seseorang yang dianggap berpengaruh dalam hidupnya. Menjadi perempuan pergerakan karena ingin menjaga NU sesuai amanat gurunya. Karena menurutnya, menjalankan amanat seorang guru adalah salah satu jalan untuk mendapat berkah dari seorang guru. Ketika ia memutuskan untuk masuk PMII, ia memang memiliki tekad yang kuat dan tidak setengah-setengah. Sampai pada akhirnya ia benar-benar merasa bahwa pilihan dia dalam menjadi perempuan pergerakan adalah suatu pilihan yang tepat di dalam hidupnya walaupun tidak mudah dalam menjalankannya. Keinginan seseorang dalam memenuhi kebutuhannya mendorong seseorang itu untuk melakukan apa saja demi memenuhi kebutuhannya. Selain kebutuhan, seseorang memiliki tujuan dari motif yang timbul dalam dirinya. Karena motif merupakan dorongan dalam diri manusia yang timbul dikarenakan adanya kebutuhankebutuhan yang ingin dipenuhi oleh manusia tersebut hingga akhirnya mereka melakukan aktivitas-aktivitas yang menurut mereka memenuhi kebutuhan tersebut.

Kedua, motif ingin mencoba hal baru, motif yang mendasari informan untuk menjadi perempuan ialah dirinya ingin mencoba sesuatu yang baru, sesuatu yang belum pernah ia lakukan sebelumnya. Karena rasa penasarannya yang tinggi, sehingga ia ingin mencoba hal tersebut. Pernyataan mengenai motifnya menjadi perempuan pergerakan. Ia ingin mencoba sesuatu yang belum pernah ia lakukan selama di sekolah, yaitu mengikuti sebuah organisasi. Jadi setelah masuk kampus, ia mulai mencoba masuk organisasi. Terakhir, motif ingin menyibukkan diri, kepribadian seseorang memang berbeda-beda setiap individunya, ada yang malas untuk melakukan sesuatu, namun ada juga yang tidak terbiasa untuk banyak berdiam diri tanpa melakukan kegiatan. Dan itu terjadi pada KOPRI yang tidak suka menyianyiakan waktunya dengan berdiam diri dan tidak melakukan sesuatu yang bermanfaat. Ia ingin menyibukkan diri dengan mengikuti organisasi, karena pribadinya yang tidak bisa diam menjadi alasan yang memang memperkuat motif untuk mengikuti KOPRI.

Pada dasarnya setiap individu akan mempunyai pemahaman dan pengetahuan mereka sendiri. Dimana konstruksi makna berasal dari pengalaman mereka yang pernah dialami, karena pengalaman hidup berbeda, orang mempunyai makna masing-masing untuk kata-kata tertentu. Inilah yang kita sebut dengan makna perorangan, tetapi bila semua makna itu bersifat perorangan, tentu tidak terjadi komunikasi dengan orang lain. Ini berarti ada makna yang dimiliki bersama, karena komunikasi sebagai pertukaran makna dimana itu ada disetiap orang yang mengirimkan pesan dan makna tersebut diharapkan dimengerti oleh penerima. Makna diri perempuan pergerakan yang masing-masing informan milikidiinternalisasikan kedalam diri masingmasing. Hal tersebut mempengaruhi perilaku mereka walaupun tidak semua perilaku informan dalam penelitian ini dipengaruhi oleh makna perempuan pergerakan. Namun pada perilaku-perilaku tertentu informan merasa terdorong oleh persepsinya tentang makna diri perempuan pergerakan.

Teori konstruksi realitas sosial juga menjelaskan bahwa setiap orang pasti memiliki suatu kebiasaan yang dilakukannya dari dalam diri sendiri maupun dari lingkungannya, karena kebiasaannya ini seseorang dapat membangun komunikasi dengan orang lain sesuai dengan tipe-tipe seseorang yang biasa disebut dengan pengkhasan. Dalam teori ini juga menyebutkan bahwa seseorang itu hidup dalam kehidupannya mengembangkan suatu perilaku repetitif yang 
biasa disebut sebagai kebiasaan. Kebiasaan ini yang memungkinkan seseorang memaknai dirinya sebagai pribadi yang bermanfaat bagi orang lain dan bisa menjadi ujung tombak peradaban.

Kemudian makna terbentuk berdasarkan hasil interpretasi melalui interaksi, komunikasi, tindakan serta situasi yang dijalankan oleh para perempuan pergerakan ini dilingkungan sekitarnya.

Hal ini membuat para perempuan pergerakan menginterpretasikan makna diri mereka bahwa dengan menjadi perempuan pergerakan ia bisa bermanfaat bagi orang lai dan bisa menjadi ujung tombak peradaban. Pemaknaan ini terjadi ketika mereka sudah menjadi perempuan pergerakan, sehingga terciptalah makna yang diberikan orang lain terhadap mereka seperti perempuan yang memberi manfaat dan perempuan yang menjadi ujung tombak peradaban. Nilai-nilai dalam masyarakat itu terbentuk dari suatu hal yang terjadi secara terus menerus dan turun temurun yang sehingga membentuk nilai yang sekarang ada, dan sering salah membedakan antara gender dengan sex (jenis kelamin). Dimana yang menganggap gender adalah suatu kodrat, laki-laki harus menjadi pemimpin dan perempuan berada dibawah laki-laki, padahal yang sebetulnya kodrat adalah jenis kelamin. Sedangkan gender itu terbentuk karena perspektif yang dikonstruksi mayarakat yang dapat berubah sewaktu-waktu. Perempuan pergerakan yang terjadi dan dimaknai oleh KOPRI di Karawang itu bisa terbentuk ketika mereka mencoba untuk keluar dari zona nyaman mereka yang akhirnya membuat mereka menjadi seperti sekarang.

Makna diri perempuan pergerakan dalam satu tempat bisa berbeda dengan tempat yang lainnya. Perempuan umumnya dan KOPRI, khususnya yang sedang peneliti jadikan infroman pasti memiliki kecenderungan untuk memberikan alasan atau makna yang berbeda-beda pada sesuatu hal, terutama makna perempuan pergerakan. Untuk menjabarkan apa itu makna diri perempuan pergerakan menurut pendapat mereka pasti di karenakan apa yang telah mereka alami atau mereka pahami dalam diri mereka selama ini. Secara keseluruhan para informan memiliki jawaban yang berbeda dan definisi yang berbeda mengenai makna diri perempuan pergerakan bagi dirinya masing-masing.

Seiring dengan perkembangan zaman saat ini membuat mereka memiliki pendapat yang benar adanya terjadi menurut versi mereka masing-masing. Perempuan pergerakan yang terjadi saat ini membuat mereka berpikir tidak selalu perempuan yang menjadi anggota komunitas atau organisasi, mereka memiliki arti dan makna tersendiri dalam menyampaikan makna diri perempuan pergerakan itu kepada peneliti yang mereka dapat dari pengalamanpengalaman yang mereka alami sendiri selama ini.

Dari hasil pengamatan dan wawancara yang dilakukan oleh peneliti, para informan ini dapat memaknai sesuatu hal itu tergantung dari pengalaman-pengalaman mereka yang mereka alami sendiri dalam hidupnya, dalam hasil pengamatan ini juga informan memiliki makna diri perempuan pergerakan yang menurutnya harus menjadi pribadi yang bisa memberi manfaat bagi orang lain dan perempuan sebagai ujung tombak peradaban. Peneliti memperoleh dua makna diri seorang perempuan pergerakan.

Makna yang pertama adalah makna diri perempuan yang memberi manfaat. Setiap kata memiliki makna masing-masing dimana suatu individu melakukan proses dalam memberikan makna terhadap suatu kata tersebut, makna adalah bagian dari yang tidak dapat dipisahkan dan selalu melekat dari apa yang kita tuturkan, ia bergantung pada persepsi, pemahaman, pengertian dan anggapan seseorang. Sebagaimana pepatah mengatakan, sebaikbaiknya manusia adalah manusia yang bermanfaat bagi orang lain, begitu juga dengan perempuan. Dikatakan perempuan pergerakan ialah perempuan yang bermanfaat untuk orang lain, yang senantiasa melakukan kegiatan positif dan bisa dirasakan orang banyak.

Makna yang kedua adalah makna diri perempuan sebagai ujung tombak peradaban, setiap yang dilakukan oleh manusia memiliki 
makna yang ingin ditunjukkan dengan cara bagaimana melakukan sesuatu, seperti halnya perempuan sebagai ujung tombak peradaban. Dimana hal ini perempuan merupakan makhluk Tuhan yang istimewa, karena keberadaannya sangatlah penting dalam menentukan masa depan peradaban. Dari beberapa kali melakukan wawancara, ada beberapa pokok perhatian bagi informan dalam memaknai diri perempuan pergerakan bagi dirinya yakni perempuan sebagai ujung tombak peradaban. Hal tersebut membuat informan memaknai dirinya sebagai perempuan sebagai ujung tombak peradaban.

Manusia pada umumnya dan para perempuan pergerakan yang berada di Karawang ini khususnya yang diteliti oleh peneliti, memiliki kecenderungan untuk memberikan kesan pada apa yang sedang atau sudah dialaminya, berdasarkan hasil data yang dilakukan dengan cara melakukan wawancara langsung secara mendalam dengan para informan, maka dihasilkan beberapa pengalaman yang berbeda dan memiliki keunikan masing-masing dari ketiga informan. Pernyataan yang dihasilkan oleh informan ini pasti berdasarkan dengan pengalaman pada setiap informan. Pengalaman adalah sesuatu yang telah terjadi dimasa lalu, pengalaman yang memiliki kesan akan selalu diingat oleh seseorang yang telah mengalami kejadian tersebut. Pengalaman memang tidak semuanya manis dan tidak selalu pahit, namun pengalaman pahit maupun manis, susah senang, suka dan duka semua tergantung pada orang yang mengalaminya, bagaimana ia menanggapinya.

Pada dasarnya, manusia memiliki pemahaman dan pengetahuan masing-masing yang berasal dari pengalaman yang pernah dialami oleh setiap manusia, karena pengalaman hidup yang berbeda. Dalam teori realitas sosial juga menjelaskan bahwa setiap orang pasti memiliki suatu kebiasaan yang dilakukannya dari dalam diri sendiri ataupun dari lingkungannya, karena kebiasaan informan ini dapat membangun pemahaman dan pengetahuan mengenai aksi kemanusiaan dan dapat membuka lapak KOPRI. Pengalaman tersebut terjadi ketika mereka para informan mengalaminya sendiri selama menjadi perempuan pergerakan.

Kemudian pengalaman tersebut berdasarkan hasil interpretasi melalui interaksi, komunikasi, tindakan serta situasi yang dijalankan oleh para perempuan pergerakan ini dilingkungan sekitarnya. Hal ini membuat para perempuan pergerakan menginterpretasikan pengalaman melakukan kegiatan aksi kemanusiaan dan membuka lapak kopri yang disesuaikan dengan apa yang telah mereka alami.

Pengalaman yang pertama adalah melakukan aksi kemanusiaan. Pengalaman setiap individu pasti berbeda-beda, tergantung pada peristiwa yang terjadi pada individu tersebut, baik itu pengalaman yang menyenangkan maupun menyedihkan dan tergantung pada bagaimana ia menanggapinya. Dia mengungkapkan bahwa merasa takut akan terjadi sesuatu yang tidak diinginkannya. Namun, dia tetap bangga telah berkontribusi untuk membantu sesama. Pengalaman yang kedua yaitu membuka lapak kopri, sebagai sarana membaca. Hal tersebut dilatarbelakangi karena hobinya yang suka baca buku dan menyayangkan buku yang telah ia baca jarang dibaca kembali sehingga ia dan teman-temannya berinisiatif untuk membuka Lapak KOPRI. Dia berharap dengan ia membuka Lapak KOPRI dapat membangkitkan semangat membaca masyarakat Karawang. Dalam kajian apapun, siapapun, dimanapun, manusia akan selalu berkomunikasi, hal ini terkait dengan prinsip komunikasi. Hal ini juga terkait dengan para perempuan pergerakan di Karawang dalam memaknai perempuan pergerakan itu sendiri dalam dirinya. Meninjau kembali fenomenologi Alfred Schutz tentang konstruksi makna yang penting dalam kajian fenomenologi, untuk mendapatkan gambaran konstruksi makna maka harus di lakukan pencarian tipikasi atau tindakan yang dilakukan oleh para informan. Pencarian makna yang dikaji oleh peneliti ialah makna diri perempuan pergerakan yang menurut para informan sesuai 
dengan pengalamannya seperti apa dan juga makna diri mereka.

Pemaknaan perempuan pergerakan ini mengalami perubahan makna dan beragam makna, hal ini berkaitan dengan situasi para informan ketika mereka menjadi perempuan pergerakan. Pemaknaan perempuan pergerakan ini terkait dengan bagaimana mereka memahami dirinya. Seperti cara mereka merekonstruksi dalam ranah koginitif individu dimana konstruksi makna itu sendiri melibatkan faktor internal, faktor eksternal, keterampilan dan juga tujuan. Ketika mereka memaknai perempuan pergerakan itu menjadi memberi manfaat dan juga menjadi ujung tombak peradaban itu berdasarkan dari apa yang mereka alami sendiri dalam dirinya, dan mereka juga memaknai diri sendiri dengan pribadi yang seperti itu. Makna yang didapat informan juga terbentuk karena adanya konstruksi makna yang terjadi dalam benak mereka masing-masing.

Makna mengenai perempuan pergerakan dan juga makna diri ini didapatkan karena mereka mempertimbangkan aspekaspek yang mereka lihat serta rasakan dari individu lain. Dari hasil penjabaran yang telah peneliti jabarkan diatas mengenai kajian yang diteliti dalam penelitian ini yakni makna perempuan pergerakan bagi perempuan yang menjadi KOPRI.

\section{SIMPULAN}

Berdasarkan penelitian yang telah di laksanakan, maka peneliti dapat mengambil kesimpulan bahwa motif perempuan menjadi KOPRI ini yaitu untuk menjalankan amanah dari sang guru bahwa harus menjaga NU, motif karena ingin mencoba hal baru dengan mengikuti organisasi saat sudah memasuki bangku perkuliahan, dan motif ingin menyibukkan diri karena sudah terbiasa banyak kegiatan sedari ia masih sekolah. Lalu makna diri perempuan pergerakan yang dimaknai dan di artikan oleh para informan ini yaitu ketika mereka melihat diri mereka sendiri dan telah mereka alami sendiri yaitu seorang perempuan bisa dikatakan perempuan pergerakan jika ia bisa memberi manfaat kepada orang lain dan juga seorang perempuan pergerakan bisa menjadi ujung tombak peradaban. Alasan yang mempengaruhi mereka dapat memaknai perempuan pergerakan ialah ketika mereka merasa dirinya bermanfaat dan menyadari akan pentingnya peran perempuan dalam menentukan masa depan peradaban suatu bangsa. Juga pengalaman setiap informan setelah mereka menjadi KOPRI yaitu telah melakukan kegiatan kemanusiaan dengan menjadi relawan bencana, menggalang dana untuk korban bencana dan membuka Lapak KOPRI sebagai sarana membaca buku untuk masyarakat Karawang.

\section{DAFTAR PUSTAKA}

Bayu Yudha Perwira. (2019). Konstruksi Makna Perempuan Perokok. Karawang: FISIP Universitas Singaperbangsa Karawang.

Burhan Bungin. (2008). Sosiologi Komunikasi: Teori, Paradigma dan Diskursus Teknologi Komunikasi. Yogjakarta: Tiara Kencana.

Brouwer, M. (1994). Psikologi Fenomenologis. Jakarta: PT Gramedia Pustaka Utama.

Creswell, J. W. (1998). Qualitative Inquiry and Research: Choosing. Among Five Tradition. SAge Publications Inc. https://doi.org/https://doi.org/10.1177/152 4839915580941

Hartutik. (2015). R.A. Kartini : Emansipator Indonesia Awal Abad 20. https://ejurnalunsam.id/index.php/jsnbl/a rticle/download/559/413/, 2, 86-96.

Ikhma Zurani. (2020). Dominasi Perempuan Pebisnis Dalam Rumah Tangga. WACANA : Jurnal Ilmiah Ilmu Komunikasi., 19.

Kompasiana. (2015). Ketika Penghasila Istri Lebih Tinggi Dari suami. Http://www.kompasiana.com/pakcah/keti ka-Penghasilan-Istri-Lebih-Tinggi-Darisuami_54f34cdf455137c2b6c705f.

Kuswarno, E. (2009). Fenomenologi: Metode Penelitian Komunikasi. Bandung: Widya Padjajaran. Bandung: Widya Padjajaran. 
Kuswarno, E. (2013). Metode Penelitian Fenomenologi: Konsepsi, Pedoman, dan Contoh Penelitian. Bandung: Widya Padjajaran.

Lexy J. Moleong, D. M. A. (2011). Metode Penelitian Kualitatif. Bandung: PT Remaja Rosdakarya.

Lexy J. Moleong, D. M. A. (2017). Metodologi Penelitian Kualitatif Edisi Revisi. Bandung: PT Remaja Rosdakarya.

Mulyana, D. (2011). Metode Penelitian Kualitatif. Bandung: PT. Remaja Rosdakarya.

Savira Gusdia. (2019). Konstruksi Makna Maskulinitas Bagi Pria Androgini. Karawang: FISIP Universitas Singaperbngsa Karawang.

Siti Wuryan. (2019). Kepemimpinan Perempuan Dalam Meningkatkan Kinerja Organisasi Pada Kopri (Korps Pmii Putri)
Wilayah Lampung. UIN Raden Intan Lampung. Jurnal Dakwah Dan Ilmu Komunikasi., 1.

Sobur, A. (2013). Psikologi Umum (Dalam Lintas Sejarah). Bandung: CV Pustaka Setia.

Sugiyono. (2013). Metode Penelitian Pendidikan Pendekatan Kuantitaif, Kualitatif, dan R\&D. Bandung: Alfabeta.

Tuwu, D. (2018). Peran Pekerja Perempuan Dalam Memenuhi Ekonomi Keluarga: Dari Peran Domestik Menuju Sektor Publik. Al-Izzah. Jurnal Hasil-Hasil Penelitian, 63. https://doi.org/https://doi.org/10.31332/ai. v13il.872

Yordani,G.(n.d.).NoTitl.http://repository.usu.a c.id/bitstream/handle/123456789/56516/ Chapter\%20II.pdf? sequence $=4$. 